\title{
The Role of Auditory Input Enhancement through Whats App in EFL Learners' Vocabulary Learning and Retention
}

\author{
Yaghoob Javadi \\ Department of Language Teaching and Translation, Varamin-Pishva Branch, Islamic Azad University, Varamin, Iran \\ Maryam Cheraghi Shehni \\ Department of Language Teaching and Translation, Varamin-Pishva Branch, Islamic Azad University, Varamin, Iran
}

\begin{abstract}
The present study investigated the effect of teaching vocabulary using auditory input enhancement via whats app on EFL learners' vocabulary learning and retention. For this purpose, 85 students were participated and those 56 students whose scores were one standard deviation above or below the mean on Preliminary English Test (PET) were selected and they were assigned into one experimental and a control group. Then they were given a 40 multiple choice vocabulary test as their pretest. The 10 -session treatment followed by teaching vocabulary using auditory input via Whats app in one experimental group and the control group had their conventional way of teaching. After the treatment, a vocabulary posttest was administered to groups in order to compare the participants' performance and to examine if or not the given instruction had any meaningful effect on their vocabulary achievement. After about 10 days after the posttest, the same vocabulary posttest was administered again to check the learners' vocabulary retention. The analysis of the test scores through an independent sample t-test and analysis of covariance (ANCOVA) indicated that auditory input enhancement through Whats app had a statistically significant effect on vocabulary learning and retention of Iranian EFL learners.
\end{abstract}

Index Terms — auditory input enhancement, vocabulary learning, vocabulary retention, whats app

\section{INTRODUCTION}

English learning is fundamental nowadays as it is considered as the international communication medium and it is also necessary for different activities, such as education, politics, and socio-economics (Mckey, 2002). On the other hand, Jesa (2008) argued that in learning a foreign language, vocabulary is considered as the basic step toward mastering a foreign language. Through vocabulary, L2 learners are able to fulfill the four language learning skills, such as listening, speaking, reading and writing (Richards \& Renandya, 2002). Lane and Allen (2010) stated that, "Vocabulary knowledge is one of the best predictors of comprehension, reading performance and school achievement" (p.364). Furthermore, Wei (2007) declared that currently long-term retention, as one of the greatest problems in learning new words, has been at the center of attention. Indeed, vocabulary retention is considered as another crucial factor in learning English as a foreign language as Mohammed (2009) defined it as the ability to keep the learned vocabulary and retrieve it after a period of time in order to use it in different language circumstances.

In addition, the researchers have noticed that English learners had limitations in the use of vocabularies and in order to solve the problems, the teachers in most classes used the most frequent way of vocabulary instruction including pronouncing the new words in line with giving their definition and spelling and finally through explaining new words' grammatical functions, which has been ascertained unsuccessful by many EFL teachers (Zoghi \& Mirzaei, 2014). Nevertheless, presenting vocabulary through these ways does not lead to any constructive result and in order to facilitate vocabulary learning and its retention, different techniques and strategies have been proposed in textbooks.

Consequently, Gascoigne (2006) stated that the most valuable technique in teaching vocabulary is input enhancement, which has been highlighted these days and the researchers focused on it in learning a language. According to Ellis (1995), input enhancement is a significant option in language teaching, which makes language learners aware of some particular target forms in the learning situation; as it draws the learners' attention to them. Moreover, Lee and Benati (2007) claimed that for language growth, input enhancement is advantageous; however, it does not guarantee that input changes into intake unless language learners are able to notice the input they are face with. According to Doughty and Williams (1998), input enhancement consists of two forms such as visual input and oral input. In this classification, the visual enhancement is related to providing learners with input enhancement via techniques such as bolding, underlining, and highlighting the target language features while the other is the auditory input enhancement which refers to providing oral input enhancement through the use of pronunciation-related features such as changes in intonation or pitch. 
On the other hand, Mobile phone is regarded as one type of the technologies that can be implemented to help learners in the process of learning a foreign language and it is dominant in most students and they are not considered just as communication devices; however, they are suitable in any types of learning (Prensky, 2005). Indeed, Thornton and Houser (2005) stated that mobile devices could be effective for delivering foreign language learning materials that is not only fast and convenient for the teacher to send, but also for the students to receive and review. According to Zhang, Song, and Burston (2011), the application of mobile devices in language learning technically called Mobile Assisted Language Learning (MALL), which has attracted language learners and teachers against controversy over the issue. Furthermore, MALL is a new type of language learning as a branch of technology-enhanced knowledge that is applied in different forms involving distant, face-to-face, or online modes. Many researchers were interested in MALL approaches, and they actively support additional studies in this discipline (Kukulska-Hulme \& Jones, 2011).

Moreover, social networking nowadays has an excellent reputation, and also exists among the most important means of communication in society and the world (Pempek Yermolayeva, \& Calvert, 2009). Social media is defined as distinct types of communication technologies that support human interaction. All generations especially the young generation tend to use this social media (Ewa, as cited in Zulbeni, 2017). As stated by Slaouti, Onat-Stelma, and Motteram (2013), WhatsApp, Skype and GO SMS Pro are the frequently used social network applications among students in learning in several countries. One of the popular types of social networking created in 2009 is WhatsApp which is popular instant massaging applicable for various devices and gadgets which allows people to exchange messages and used by more than 350 million users in 2013 (Cohavi, 2013).

As Susilo (2014) stated, WhatsApp has become the "communication portal" for social networking that has rapidly changed the way of communication. Jadhav, Bhutkar and Mehta (2013) declared that this is one of the technology developments that are generally utilized on specified mobile phones and computers and moreover, the performance of WhatsApp is the most extensive messenger applications between the college scholars. In teaching learning, teachers can use WhatsApp as a medium to facilitate students in learning English as Kheryadi (2017) stated that students are familiar with technologies as an alternative device to provide new learning experiences for them. Unlike the other kinds of communication and any other technologies that do not function and students do not use after school hours, WhatsApp permits easy and quick change of links to study. Using WhatsApp to send homework materials can enable the teachers to make sure about receiving the message (Bouhnik \& Deshen, 2014).

Although using MALL and social networks as complementary instruments for students to learn a language better has been carried out quite a lot in Iran such as, Khabiri and Khatibi (2013) and Yousefzadeh (2012) who proved the effectiveness of MALL in language learning Fattah (2015) who used WhatsApp to examine its effect in developing students' writing skills. However, there is not enough research to state confidently that auditory input enhancement can be regarded as an alternative to other forms of learning. In addition, no research has been carried out in literature to find if teaching auditory input enhancement through social networking is effective in developing students' vocabulary learning and retention. As a result, based on the significance of vocabulary and its retention in learning a foreign language and the role of mobile learning as well as social networking such as WhatsApp, the present research aims at inspecting the effect of auditory input enhancement through WhatsApp on the learning and retention of vocabulary among EFL learners.

\section{REVIEW OF LITERATURE}

\section{A. Vocabulary Learning and Retention}

Merriam-Webster Learner's Dictionary (2003) illustrated that vocabulary means the words that make up a language. Moreover, earlier, in language programs, vocabulary teaching and learning were often given little priority but lately, there has been a great concentration to it and its significant role in learning and teaching (Richards \& Renandya, 2002). Knowledge of vocabulary has an important role in learning a language. Vocabulary is the building blocks of language, and language is essential in the process of achieving success (Graves, 2006). According to Cohen and Weaver (2005), vocabulary learning is a skill-related strategy that cuts across all four skills. As Hornby (2004) put forward, individuals have the ability for remembering or recalling things such as words, events, memories and the like after a short or long time, which is called retention. Regarding vocabulary retention, Min and Hsu (2008) declared that all learners hold a lot of receptive vocabulary knowledge more than one month but approximately half of them demonstrate a noteworthy decrease in profitable word knowledge. Two kinds of vocabulary retention exist: immediate retention and delayed retention. The first is defined as the level of retention of the newly known piece of information as measured instantaneously by a test after the experimental teaching which can be considered as medium-term retention (Souleyman, 2009). Nevertheless, Souleyman defined the latter as the level of retention of the target piece of information lately achieved through the experimental instruction, as measured by a test on that new data. In this specific case, the delayed test was given to the learner's month or later, which can be referred to as long-term retention.

\section{B. Input Enhancement and Auditory Input Enhancement}

The term input enhancement as a teaching technique was designed to substitute the term "grammatical consciousness-raising" (GCR) because the scholars who proposed this term believed that the GCR is not efficient for enhanced learning that usually takes place in natural or accidental contexts as opposed to an academic or purposefully 
educational settings (Ellis, 2008, as cited in Okar \& Shahidy, 2018). As Long and Robinson (1998) stated, "the perceptual salience of the target items could be increased" in the input (p. 24). As stated by Gascoigne (2006), making input prominent can be noticeable in the context of planned structures, providing metalinguistic illuminations and negative confirmation through using of particular adjustment, making learners indulge in input, teaching learners in a way to be able to improving the input and texts. Auditory input improvement consist of the management of listening materials, such as placing a short pause before and/or after the intended items or increasing the volume of intended items in the text. Moreover, Gascoigne (2006) added that by emphasizing on stress, intonation, or signs, an "oral equivalent of textual enhancement" could be done. Seyedtajaddini (2014) stated that auditory input enhancement is on the basis of managing audio materials in order to make the target forms more salient and get the learners' attention toward them.

\section{Mobile-assisted Language Learning (MALL)}

MALL is defined as formal and informal learning mediated through handled devices that can be used anytime and anywhere (Kukulska-Hulme \& Shield, 2008). Although Pettit and Kukulska-Hulme (2007) claimed that mobile learning associates with the use of all portable learning materials containing books, audio-CDs, audio-cassettes, portable DVD players and radios, mobile learning frequently focuses on the newest technologies. Trifanova, Knapp, Ronchetti and Gamper (2004) described mobile devices as any small, autonomous and unobtrusive device that can go along with everyone in every moment. Generally, as stated by Geddes (2004), mobile learning is identified by the tools used. Comparable with others, Traxler (2005) proposed that mobile learning possibly refers to any educational provision in which either the sole or the dominant technologies are handheld by laptop devices. As summarized by Sa'aleek (2014), mobile technology efficiently can increase language skills because of features like accessibility, immediacy, interactivity, and permanency. Nevertheless, Chinnery (2006) declared that MALL also has challenges like reduced screen sized, limited quality of audiovisual, fundamental keyboarding, and one finger data entry, and controlled power.

\section{Social Networking (WhatsApp)}

The mobile devices such as iPads, iPods, tablets, Mp3 players mobile phones and so on are used in mobile learning technologies. Mobility and interactivity are provided for students through mobile devices (Trentin \& Repetto, 2013). Social networks are considered as a type of internet websites in which individuals, groups, and organizations come together based on one or more common conditions and they share their information, subjects and contexts. Moreover, when social networks were used as an educational method, they would cause creativity and interpersonal relationship strength (Collin, Richardson \& Third, 2011). Among L2 practitioners, the use of social networking is very prevalent in creating online communities. Likewise, L2 learners make social groups and simulate learning circumstances through variety of social media communicate with others further than the L2 classrooms (Sekiguchi, 2012). As defined by Bryer and Zavatarro (2001), social media are technologies that improve social interaction, make collaboration possible, and enable discussion among learners and these technologies include blogs, wikis, media sharing tools, networking platforms, and virtual worlds. Olanof (2012) defined WhatsApp instant messaging as a cross-platform smartphone messenger that applies users' existing Internet data plan to assist the network socially in real-time. As stated by Sushma (2012), throughout June 2013, WhatsApp Inc. declared that they controlled 27 billion messages every 24 hours. WhatsApp are used by students through a variety of mobile devices, such as smartphones, Galaxy tablets, and they can send message to another through texts, images, videos, and so on. Class WhatsApp groups are implemented for four primary purposes: 1 . communicating with students; 2 . maintaining the social atmosphere; 3 . creating dialogue and encouraging sharing between students; and 4. as a learning platform (Bere, 2013). According to Bouhnik and Deshen (2014), WhatsApp enables easy and rapid links transference to study materials. Sending homework materials by WhatsApp confirm that all students receive the message, whether it is a video specified for class or copy of an answer to an exercise sent outside the classroom hours.

\section{E. Related Studies}

Basoglu and Akdemir (2010) studied the efficacy of a mobile phone-based flashcard application for L2 English vocabulary achievement. The findings of their study revealed that, this type of instruction is more effective in increasing students' vocabulary knowledge.in addition, learning English vocabulary through mobile phones was fun for students. Seyedtajaddini (2014) has done a research in order to investigate the effect of audio input enhancement on EFL learners' grammar learning from varying proficiency levels. To this end, 30 participants were selected from the intermediate and advanced EFL learners at Goldis institute in Salmas, Iran. Based on the findings of the study, it was proved that there is a significant difference between two groups based on the use of audio input enhancement representing that the highly proficient learners performed better than the low proficient learners. In addition, Homayounmehr and Pishdadi Motlagh (2015) have done a study who investigated the effect of input enhancement on L2 vocabulary and to examine the effect of different types of input enhancement factors such as bolding, underlining, and capitalizing on L2 learners' vocabulary learning. The results of study indicated that three types of inputs were effective in responding to target vocabulary words but the bolding group performed better than the other groups. Also, bolding target words were more effective in fostering L2 learners' vocabulary knowledge learning. The results also proposed that using bolding as a type of input enhancement technique had a significant effect in developing learners' 
awareness in vocabulary learning. There is a study by Homayounmehr and Pishdadi Motlagh (2015) who investigated how input enhancement devices of bolding, underlining, and capitalizing affect L2 learners' vocabulary learning. The result of the study showed that all three inputs were effective regarding target vocabulary words but the bolding group outperformed the other groups. In addition, it can be stated that in terms of their efficacy, capitalizing is the least effective input compared to underlining and bolding input. In addition, AbdAlfattah (2015) has done a study to check the usefulness of using a WhatsApp Messenger as one of mobile learning techniques to improve students' writing skills. 30 students from Saudi Arabia were selected and they were divided into two groups (experimental and control). The experimental group used WhatsApp technology to develop their writing skills; while, the control group was taught the same skill in the classroom. The findings indicated that using WhatsApp had positive effects on students' writing skills.

Furthermore, there is another study which had been done by Ashiyan and Salehi (2016) who investigated the effect of WhatsApp on school work and out of school work. 80 learners were participated while 60 participants were selected as the intermediate level and were assigned into experimental and control groups. The results presented that the experimental group who used WhatsApp application in learning collocation performed much better than the control group in posttest. Jafari and Chalak (2016) carried out a study in order to examine the role of WhatsApp in the vocabulary learning improvement of Iranian junior high school EFL students. 60 students comprising of 30 male and 30 female students studying at two male and female junior high schools in Isfahan, Iran took part in their study. The findings revealed that using WhatsApp had significant role in vocabulary learning of the students while there was not a significant difference between male and female students after using WhatsApp regarding their vocabulary knowledge. Moreover, Xodabande (2017) has done a research on the effectiveness of using social media network Telegram in teaching English language pronunciation to Iranian EFL learners. The results revealed that the pronunciation of participants in the experimental group improved significantly compared to the control group but there was no significant effect in pronunciation of participants in experimental group from post-test to delayed test which was administered four weeks later. The results of the study revealed that using social media networks in teaching language features can be very effective. Moreover, Abdulkhaleq and Hassan (2018) investigated the efficacy of eLearning by using a WhatsApp, at King Khalid University in Saudi Arabia. The purpose of the study was to determine whether the levels of motivation, content knowledge and grades of the students developed after instructing through WhatsApp apart from traditional classroom lectures. The findings indicated that the experimental group outperformed than the control group and it is proved that using WhatsApp is beneficial in language learning.

In line with the literature review and the associated research in this domain, the subsequent research questions were raised in the present study.

Q1: Does auditory input enhancement through Whats app have any statistically significant effect on vocabulary learning of Iranian EFL learners?

Q2: Does auditory input enhancement through Whats app have any statistically significant effect on vocabulary retention of Iranian EFL learners?

\section{METHOD}

\section{A. Participants}

The population of this study was 85 students studying in. They were female within the mean range of 25 years old and they were at intermediate level. Fifty five learners whose scores were one standard deviation below and above the mean were selected based on their performance on Preliminary English Test (PET). 26 homogenous participants, were considered as control group and 29 homogenous participants, were considered as experimental group. The experimental group received auditory input enhancement instruction through Whats App as their treatment and the control group followed the conventional method suggested by the institute.

\section{B. Materials and Instruments}

\section{Preliminary English Test (PET)}

In order to be assured of the homogeneity of the participants in terms of English language proficiency, and to ensure that they were all at intermediate level, a PET was administrated. PET is considered as the second level of Cambridge ESOL that exams four language skills (speaking, writing, listening, and reading) and is a valuable qualification if you want to work or study abroad or to develop a career in international business. Since the focus of the present study was not on speaking ability of the participants, this part was discarded in administration of PET. The time allocated for this test is 2 hours.

2. Vocabulary Pretest

A researcher-made test containing 40 multiple-choice items was given. The test is designed in line with those vocabularies, which was taught during the semester. The aim of pretest is to check how much participants are acquainted with these vocabularies. The time allocated for this test is 40 minutes.

3. Vocabulary Posttest and Delayed Posttest

At the end of the treatment, the same piloted researcher-made pretest was administered as a post-test in order to investigate the students' learning of vocabulary and the differences between two groups. Moreover, after the end of the 
10-session treatment, the same test was given to the two groups to check their performances and to investigate the effect of the instruction on the learners' vocabulary retention.

4. Course book

In the present study, the participants in both groups received instructions based on the same course book, which was American English File Book 2, written by Oxenden, Latham-Koenig, and Seligson (2008). This textbook is taught to intermediate learners at Iranmehr language school, and it contains nine units focusing on all four skills.

\section{Whats App application}

This application can be installed on different types of smart phones such as iPhone, Android, Blackberry, and Nokia and it allows users to send free messages to each other via Internet.

\section{Data Collection Procedures}

Following the homogeneity of the students based on the PET, the vocabulary pretest was administered. Afterwards, the results of the vocabulary pre-test were analyzed to ensure the homogeneity of the participants in terms of vocabulary knowledge before the treatment. The treatment took 10 sessions. The classes were assigned to one control and one experimental group. The experimental groups was exposed to learning vocabulary through reading and by means of Whats App and through voice messages while the control group was exposed to learning vocabulary based on conventional method suggested by the institute. It should be noted that the first session after the pretest was allocated to providing the learners' mobile contact information and making the group in the Whats App and adding the learners to a group of Whats App created by the teacher. In fact, the voice message group, the teacher taught the reading passage of the course book and defined the keywords in each text, and provided the definitions, synonyms, and antonyms regarding those keywords of the reading passage in the class. A day after the class, the teacher read the vocabulary items and gave the definitions, synonyms, and antonyms (where possible) and shared it on the Whats app group. In fact, these vocabulary items were read through repetition several times to make them as unnatural as possible and gain the students' attention. The learners were asked to listen to the files through Whats App on their mobile phones at home, as well. In contrast, the teacher employed the conventional way of teaching vocabulary in the control group through providing the meaning of each new vocabularies and checking their pronunciation and looking the new words up in dictionary and making sentences by those words. After the 10-session treatment, the teacher gave them the vocabulary immediate post-test. After about 10 days, the same vocabulary test, used as the immediate posttest was administered to enable the researcher to compare the participants' performance and examine their vocabulary retention.

\section{Data Analysis}

The following procedure was used to analyze the data. As for descriptive statistics, means and standard deviation were drawn upon. The reliability of the PET and vocabulary test was calculated through Cronbach alpha formula. With the aim of taking the first research question into consideration, an independent samples t-test was run to compare the significant difference between the groups' means while Ancova was used in order and to answer the second research question.

\section{RESULT}

At the outset of the study, the PET was given to a group of 30 EFL learners bearing almost the similar individualities as the intended sample. Table 1 reports the descriptive statistics of the PET in the piloting phase.

TABLE 1:

DESCRIPTIVE STATISTICS FOR PILOTING THE PET

\begin{tabular}{|c|c|c|c|c|c|c|c|}
\hline & $\begin{array}{l}\mathrm{N} \\
\text { Statistic }\end{array}$ & $\begin{array}{l}\text { Minimum } \\
\text { Statistic }\end{array}$ & $\begin{array}{l}\text { Maximum } \\
\text { Statistic }\end{array}$ & $\begin{array}{l}\text { Mean } \\
\text { Statistic }\end{array}$ & $\begin{array}{l}\text { Std. Deviation } \\
\text { Statistic }\end{array}$ & $\begin{array}{l}\text { Skewness } \\
\text { Statistic }\end{array}$ & Std. Error \\
\hline PET Pilot & 30 & 35.50 & 71.00 & 53.233 & 10.27697 & -.270 & .427 \\
\hline Valid N (listwise) & 30 & & & & & & \\
\hline
\end{tabular}

The reliability of the PET scores taken from the participants at the piloting stage was calculated through using Cronbach's alpha coefficient. The estimated alpha was .795, which is a good index of reliability.

In addition, the vocabulary pretest was given to a group of 30 EFL learners who almost had the same individualities as the intended sample. Through an item analysis procedure such as item discrimination and item facility, all items were checked. Fortunately no mal-functioning items were identified. Table 2 reports the descriptive statistics of the vocabulary pretest in the piloting phase.

TABLE 2:

Descriptive Statistics for PILOTING The Vocabulary PRETest

\begin{tabular}{|c|c|c|c|c|c|c|c|}
\hline & $\begin{array}{l}\mathrm{N} \\
\text { Statistic }\end{array}$ & $\begin{array}{l}\text { Minimum } \\
\text { Statistic }\end{array}$ & $\begin{array}{l}\text { Maximum } \\
\text { Statistic }\end{array}$ & $\begin{array}{l}\text { Mean } \\
\text { Statistic }\end{array}$ & $\begin{array}{l}\text { Std. Deviation } \\
\text { Statistic }\end{array}$ & $\begin{array}{l}\text { Skewness } \\
\text { Statistic }\end{array}$ & Std. Error \\
\hline Pretest Pilot & 30 & 6.00 & 36.00 & 21.0667 & 8.80804 & -.114 & .427 \\
\hline Valid N (listwise) & 30 & & & & & & \\
\hline
\end{tabular}


The reliability of the vocabulary scores taken from the learners in the piloting phase was assessed by running Cronbach's alpha coefficient. The alpha index of .895 was an indication of a good reliability of the scores. Moreover, the item-total correlation to the reliability was inspected and no negative correlation was found; hence, well-functioning of the items was further approved.

In addition, the vocabulary posttest was administered to a group of $30 \mathrm{EFL}$ learners bearing almost the same characteristics as the target sample. All items went through an item analysis procedure, including item discrimination and item facility. Fortunately no mal-functioning items were identified.

TABLE 3:

Descriptive Statistics for Piloting the Vocabulary (DElayed) PostTest

\begin{tabular}{|c|c|c|c|c|c|c|c|}
\hline & $\begin{array}{l}\mathrm{N} \\
\text { Statistic }\end{array}$ & $\begin{array}{l}\text { Minimum } \\
\text { Statistic }\end{array}$ & $\begin{array}{l}\text { Maximum } \\
\text { Statistic }\end{array}$ & $\begin{array}{l}\text { Mean } \\
\text { Statistic }\end{array}$ & $\begin{array}{l}\text { Std. Deviation } \\
\text { Statistic }\end{array}$ & $\begin{array}{l}\text { Skewness } \\
\text { Statistic }\end{array}$ & Std. Error \\
\hline Posttest Pilot & 30 & 11.00 & 35.00 & 22.5667 & 7.10844 & .011 & .427 \\
\hline Valid N (listwise) & 30 & & & & & & \\
\hline
\end{tabular}

The reliability of the vocabulary scores taken from the learners in the piloting phase was assessed by running Cronbach's alpha coefficient. The alpha index of .828 was an indication of a good reliability of the scores. Moreover, the item-total correlation to the reliability was inspected and no negative correlation was found; hence, well-functioning of the items was further approved.

Then, the piloted PET test was given to 85 participants with the purpose of assisting the researcher to select the homogenous participants of the study. The statistics related to the 85 test takers is reported in Table 4 .

TABLE4:

DESCRIPTIVE STATISTICS OF PET SCORES FOR THE INITIAL GROUP

\begin{tabular}{|c|c|c|c|c|c|c|c|c|c|}
\hline & $\begin{array}{l}\mathrm{N} \\
\text { Statistic }\end{array}$ & $\begin{array}{l}\text { Minimum } \\
\text { Statistic }\end{array}$ & $\begin{array}{l}\text { Maximum } \\
\text { Statistic }\end{array}$ & $\begin{array}{l}\text { Mean } \\
\text { Statistic }\end{array}$ & $\begin{array}{l}\text { SD } \\
\text { Statistic }\end{array}$ & $\begin{array}{l}\text { Skewness } \\
\text { Statistic }\end{array}$ & Std. Error & $\begin{array}{l}\text { Kurtosis } \\
\text { Statistic }\end{array}$ & Std. Error \\
\hline PET & 85 & 25.00 & 66.00 & 47.06 & 9.552 & -.118 & .261 & -.727 & .517 \\
\hline Valid N (listwise) & 85 & & & & & & & & \\
\hline
\end{tabular}

Based on the values reported in Table 4, the skewness ratio $(-.118 / .261=-.45)$ and kurtosis ratio $(-.727 / .517=-1.41)$ values fell within the range of -1.96 and +1.96 which assure the normality of distribution (Tabachnick \& Fidell, 2007). Additionally, the minimum score was 25 and the maximum score was 66 (Mean $=47.06, \mathrm{SD}=9.55$ ). Consequently, the researcher selected those students whose PET scores fell within the range of -1 SD and +1 SD (37.51 to 56.61) in order to choose 55 individuals as the participants of the study. Table 5 presents the descriptive statistics pertinent to the remaining 55 test takers.

TABLE 5:

\begin{tabular}{|c|c|c|c|c|c|c|c|c|c|}
\hline & $\begin{array}{l}\mathrm{N} \\
\text { Statistic }\end{array}$ & $\begin{array}{l}\text { Minimum } \\
\text { Statistic }\end{array}$ & $\begin{array}{l}\text { Maximum } \\
\text { Statistic }\end{array}$ & $\begin{array}{l}\text { Mean } \\
\text { Statistic }\end{array}$ & $\begin{array}{l}\text { SD } \\
\text { Statistic }\end{array}$ & $\begin{array}{l}\text { Skewness } \\
\text { Statistic }\end{array}$ & Std. Error & $\begin{array}{l}\text { Kurtosis } \\
\text { Statistic }\end{array}$ & Std. Error \\
\hline Selected & 55 & 38.00 & 56.50 & 47.07 & 5.781 & .137 & .319 & -1.156 & .628 \\
\hline Valid N (listwise) & 55 & & & & & & & & \\
\hline
\end{tabular}

As intact classes were used in this study, equal assignment of the homogenous participants into two groups was not feasible. The initial 85 learners were already assigned into 8 classes. Therefore, the random assignment was done classwisely (four classes as experimental group and four classes as control one). This process assigned 26 of the homogenous learners into the control group and 29 of them into the experimental group.

Then the vocabulary pretest, it was administered to the 55 selected participants of the experimental and control groups. After the administration, the obtained scores were analyzed through running an independent samples t-test. Descriptive statistics pertinent to this administration are presented in Table 6. As reported, the control group $(M=22.58$, $S D=2.37)$ and the experimental group $(M=22.31, S D=2.88)$ obtained relatively close scores on the pretest.

TABLE 6:

DESCRIPTIVE STATISTICS OF THE INITIAL VOCABULARY PRETEST

\begin{tabular}{llllllllll}
\hline & N & Minimum & Maximum & Mean & SD & \multicolumn{2}{l}{ Skewness } & \multicolumn{2}{c}{ Kurtosis } \\
& Statistic & Statistic & Statistic & Statistic & Statistic & Statistic & Std. Error & Statistic & Std. Error \\
\hline Control & 26 & 19.00 & 27.00 & 22.5769 & 2.36936 & .395 & .456 & -.791 & .887 \\
\hline Experimental & 29 & 18.00 & 28.00 & 22.3103 & 2.87977 & .485 & .434 & -.631 & .845 \\
\hline Valid N (listwise) & 26 & & & & & & & & \\
\hline
\end{tabular}

The skewness and kurtosis ratio (Statistics/ Std. Error) values for both distributions fell within the legitimate range for normal distribution, i.e. \pm 1.96 ; thus running a parametric independent samples t-test was legitimized. In order to see if the differences between the mean scores are significant, the results of independent t-test were inspected (Table 7). At first, it was required to check the supposition of homogeneity of differences. As reported in Table 7, this supposition was seen (Levene's $F=1.065, p=.307>.05$ ). Therefore, the result was reported with assumption of equal variances (first raw in the table). 
TABLE 7:

INDEPENDENT SAMPLES T-TEST: VOCABULARY PRETEST BY TWO GROUPS

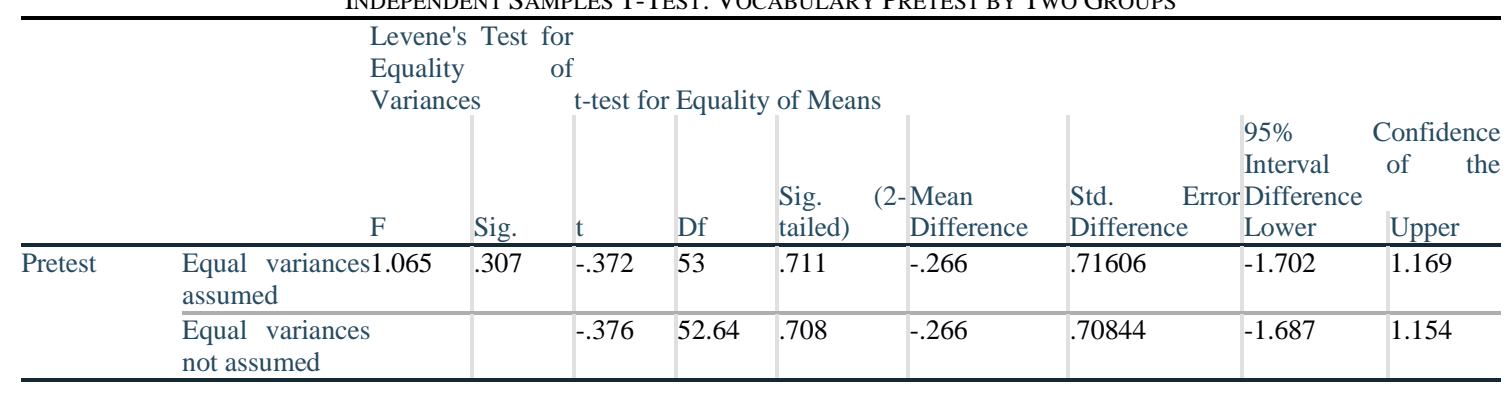

The obtained results indicated that there was no statistically significant differences between experimental and control participants' means on the vocabulary pretest $\left(t_{(53)}=.372, p=.711>.05\right)$. Therefore, the researcher was assured of the initial homogeneity of the participants in terms of their vocabulary knowledge. After making sure of the reliability of the vocabulary (delayed) posttest, it was administered to the 55 selected participants of the experimental and control groups once at the end of the treatment and once two weeks after. Descriptive statistics pertinent to this administration are presented in Table 8 and Table 9.

TABLE 8:

DESCRIPTIVE STATISTICS OF THE VOCABULARY POSTTEST

\begin{tabular}{|c|c|c|c|c|c|c|c|c|c|}
\hline & $\begin{array}{l}\mathrm{N} \\
\text { Statistic }\end{array}$ & $\begin{array}{l}\text { Minimum } \\
\text { Statistic }\end{array}$ & $\begin{array}{l}\text { Maximum } \\
\text { Statistic }\end{array}$ & $\begin{array}{l}\text { Mean } \\
\text { Statistic }\end{array}$ & $\begin{array}{l}\text { SD } \\
\text { Statistic }\end{array}$ & $\begin{array}{l}\text { Skewness } \\
\text { Statistic }\end{array}$ & Std. Error & $\begin{array}{l}\text { Kurtosis } \\
\text { Statistic }\end{array}$ & Std. Error \\
\hline$\overline{\text { Control }}$ & 26 & 21.00 & 30.00 & 24.80 & 2.607 & .477 & .456 & -.512 & .887 \\
\hline Experimental & 29 & 22.00 & 33.00 & 27.00 & 3.150 & .103 & .434 & -1.210 & .845 \\
\hline Valid N (listwise) & 26 & & & & & & & & \\
\hline
\end{tabular}

As reported, the control group $(M=24.81, S D=2.61)$ and the experimental group $(M=27.00, S D=3.15)$ obtained relatively different scores on the posttest. The skewness and kurtosis ratio (Statistics/ Std. Error) values for both distributions fell within the legitimate range for normal distribution, i.e. \pm 1.96 . The two groups took the same test as delayed posttest with two weeks interval. Table 9 reports the results

TABLE 9:

DescriPTIVe Statistics OF THE Vocabulary Delayed PostTEST

\begin{tabular}{llllllllll}
\hline & N & Minimum & Maximum & Mean & SD & \multicolumn{2}{l}{ Skewness } & \multicolumn{2}{c}{ Kurtosis } \\
& Statistic & Statistic & Statistic & Statistic & Statistic & Statistic & Std. Error & Statistic & Std. Error \\
\hline Control & 26 & 19.00 & 28.00 & 23.6154 & 2.46701 & -.141 & .456 & -.704 & .887 \\
\hline Experimental & 29 & 21.00 & 32.00 & 26.2069 & 2.82058 & .163 & .434 & -.704 & .845 \\
\hline Valid N (listwise) & 26 & & & & & & & & \\
\hline
\end{tabular}

As reported, the control group $(M=23.62, S D=2.47)$ and the experimental group $(M=26.21, S D=2.82)$ obtained relatively different scores on the delayed posttest. The skewness and kurtosis ratio (Statistics/ Std. Error) values for both distributions fell within the legitimate range for normal distribution, i.e. \pm 1.96 .

As analyzing the results of the pretest scores obtained by two groups (Table 8) showed homogeneity of the two groups at the outset, in order to answer the first research question of the study, the posttest scores of the two groups were compared. After the administration, the obtained scores were analyzed through running an independent samples ttest. Descriptive statistics pertinent to this administration are presented in Table 10. As reported, the control group $(M=$ $24.81, S D=2.61)$ and the experimental group $(M=27.00, S D=3.15)$ obtained relatively close scores on the pretest.

TABLE 10:

DESCRIPTIVE STATISTICS OF THE VOCABULARY POSTTEST By TwO GROUPS

\begin{tabular}{llllll}
\hline & Group & N & Mean & Std. Deviation & Std. Error Mean \\
\hline \multirow{2}{*}{ Posttest } & Experimental & 29 & 27.0000 & 3.15096 & .58512 \\
\cline { 2 - 5 } & Control & 26 & 24.8077 & 2.60798 & .51147 \\
\hline
\end{tabular}

In order to see if the differences between the mean scores are significant, the results of independent t-test were inspected (Table 11). 
TABLE 11:

INDEPENDENT SAMPLES T-TEST: VOCABULARY POSTTEST BY TWO GROUPS

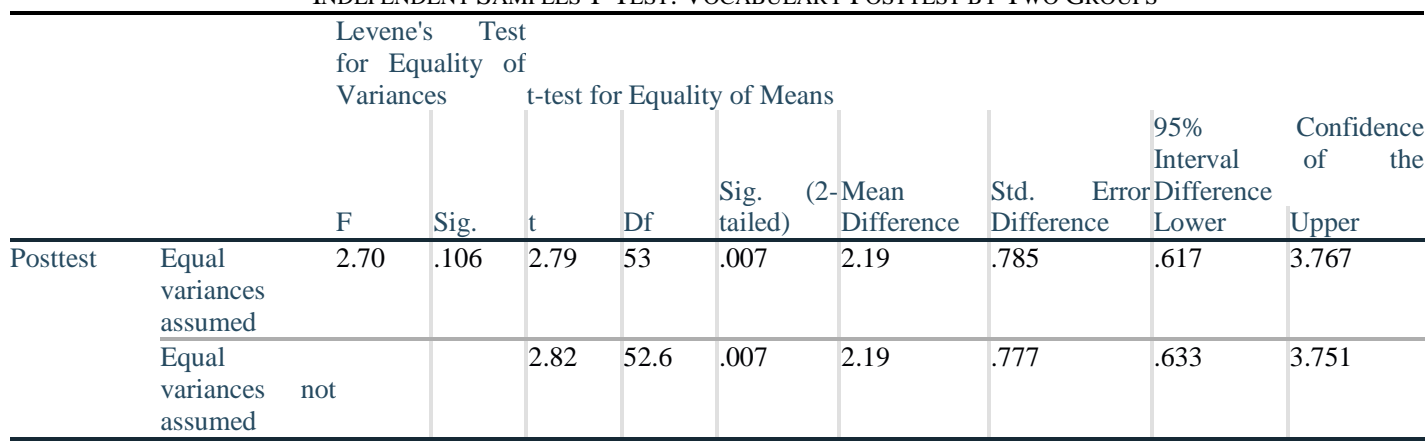

In the beginning, it was necessary to check the supposition of homogeneity of differences. As reported in Table 11, this supposition was seen (Levene's $F=2.708, p=.106>.05$ ). Therefore, the result was reported with assumption of equal variances (first raw in the table). The obtained results indicated that there was a statistically significant differences between experimental and control participants' means on the vocabulary posttest $\left(t_{(53)}=2.79, p=.007<.05\right.$, Cohen's $d$ $=.767$, representing almost a large effect size). Therefore, the first null hypothesis, which stated "auditory input enhancement through Whats app does not have any statistically significant effect on vocabulary learning of Iranian EFL learners", was rejected.

Answering the second research question required comparison of delayed posttest scores. However, as the posttest scores of the two groups were significantly different, this difference had to be taken into account. Therefore, an Analysis of Covariance (ANCOVA) was run to probe the second research question. However, before running the test, some test specific assumptions had to be checked. ANCOVA was used in order to answer the second research questions, after testing the preliminary assumptions. The results of the test are accessible in Table 12. This test will show if or not the groups are meaningfully different regarding vocabulary retention scores (the delayed posttest scores when controlling for the impact of posttest scores).

TABLE 12:

THE ANCOVA TEST RESUlTS FOR THE TwO GROUPS’ VOCABULARY RETENTION SCORES

\begin{tabular}{|c|c|c|c|c|c|c|}
\hline Source & $\begin{array}{l}\text { Type III Sum of } \\
\text { Squares }\end{array}$ & df & Mean Square & $\mathrm{F}$ & Sig. & Partial Eta Squared \\
\hline Corrected Model & $419.604^{\mathrm{a}}$ & 2 & 209.802 & 230.268 & .000 & .899 \\
\hline Intercept & 5.037 & 1 & 5.037 & 5.528 & .023 & .096 \\
\hline Posttest & 327.534 & 1 & 327.534 & 359.485 & .000 & .874 \\
\hline Group & 6.145 & 1 & 6.145 & 6.745 & .012 & .115 \\
\hline Error & 47.378 & 52 & .911 & & & \\
\hline Total & 34792.000 & 55 & & & & \\
\hline Corrected Total & 466.982 & 54 & & & & \\
\hline
\end{tabular}

As it is shown in Table 12, after modifying the delayed posttest scores for the probable impact of the posttest, there was a difference between the two groups on the scores $\left(F_{(1,52)}=6.745, p=.012<.05\right.$, partial eta squared $=.115$ representing a medium effect size). It was proved that there were significant changes among the two groups' means on the delayed posttest of vocabulary retention while controlling for the possible effects of the posttest. Table 13 presents the pairwise comparison of the adjusted means on vocabulary retention scores for each group. Here, the effect of the posttest scores has been statistically removed.

TABLE 13: BONFERRONI PAIRWISE COMPARISON OF ADJUSTED MEANS ON DELAYED POSTTEST SCORES

\begin{tabular}{|c|c|c|c|c|c|c|}
\hline \multirow[b]{2}{*}{ (I) Group } & \multirow[b]{2}{*}{ (J) Group } & \multirow{2}{*}{$\begin{array}{l}\text { Mean Difference (I- } \\
\text { J) }\end{array}$} & \multirow{2}{*}{ Std. Error } & \multirow[b]{2}{*}{ Sig. } & \multicolumn{2}{|c|}{$95 \%$ Confidence Interval for Difference } \\
\hline & & & & & Lower Bound & Upper Bound \\
\hline Experimental & Control & $.717^{*}$ & .276 & .012 & .163 & 1.271 \\
\hline Control & Experimental & $-.717^{*}$ & .276 & .012 & -1.271 & -.163 \\
\hline
\end{tabular}

Based on estimated marginal means: Experimental $=25.321$; Control $=24.604$

Covariate is evaluated at the following value: Posttest $=25.9636$

Based on the results of the study, there was a difference between the vocabulary delayed posttest scores of control and experimental groups, when the scores are used to control posttest variances (adjusted $\mathrm{MD}=.717, \mathrm{SE}=.276, p$ $=.012<.05$ ), the experimental group outperforming the control group; thus, the second null hypothesis, which indicated "auditory input enhancement through Whats app does not have any statistically effect on vocabulary learning of Iranian EFL learners" was also rejected. 
The findings of the study are in line with the findings of Basoglu and Akdemir (2010) who found that learning English vocabulary through mobile phones is useful. Additionally, the present findings are in accordance with those of Ashiyan and Salehi (2016) who investigated the effectiveness of WhatsApp in learning collocation performed much better than the control group in posttest. The results are also in line with Jafari and Chalak (2016) who indicated the efficacy of WhatsApp in the vocabulary learning improvement of Iranian junior high school EFL students. Also, the present findings are in line with Xodabande (2017) who showed that teaching through Telegram as a type of social networks could improve the pronunciation of the experimental group.

\section{CONCLUSION}

The results of the study indicated that although providing auditory input is effective in the learning and retention of vocabulary. However, the results can find support from Krashen's (1985) input hypothesis that highlights the role of comprehensible input in learning a language. The findings of this study enable the researcher to state that Whats app can be used as an excellent source of comprehensible input because the learners can repeatedly be exposed to the target issues until they feel they have learned the material. Also, the call of social networks and their ease of process are two benefits which can improve learning. Moreover, the findings can find support Sharwood Smith's (1993) input enhancement theories. The results indicated that the use of Whats app could raise the learners' consciousness toward the messages they received. Also, the saliency of input was assured via the application of Whats app messages. As the results of the delayed posttest showed, Whats app could enhance the participants' vocabulary recall and retention that implies the positive effect of social networks and urges the researcher to conclude that Whats app could attract the attention of the learners. Thus, seeking ways of input provision that are more attractive for EFL learners could be concluded. Another point to mention is the advantage of using mobile phones for language teaching and learning in general and using social networking such as Whats app. Whats app and other social networks can be practical in teaching vocabulary to students because they are easy to operate and seem to be preferred by many young learners. They can extend learning to out of the classroom settings, and thus students can have unlimited access to their peers and teachers at any time and in any place. Furthermore, Whats app could be a valuable source of encouraging students to learn vocabulary because it can help teachers and students communicate with more ease.

Instructors are recommended to employ adjusted materials consistent with the results of the present study in order to assist learners improve their vocabulary learning. They also can conclude that the practice of auditory input through Whats app is advantageous and they can take them into consideration in their process of their teaching. By providing insights gained from the results of this study, teachers can develop an awareness regarding the positive effect of auditory input in Whats app and consequently, they can provide learners with better learning opportunities outside the classroom. In addition, teachers can increase learners' vocabulary learning and retention through listening audio provided in the Whats app. Focusing on vocabulary items through audio messages would be effective and can help learners in enlightening their vocabulary learning and retention. The findings might be helpful in designing materials in which the use of Whats app is taken into account to the extent possible particularly for the purpose of teaching vocabulary.

\section{REFERENCES}

[1] AbdAlfattah, S. (2015). The Effectiveness of Using a WhatsApp Messenger as One of Mobile Learning Technique to Develop Students' Writing Skills. Journal of Education and Practice, 6(2), 32-48.

[2] Abdulkhaleq, Q., \& Hassan, A. (2018). The impact of WhatsApp on learners' achievement: A case study of English language majors at King Khalid University. International Journal of English Language Education, 6 (2), 68-81.

[3] Ashiyan, Z., \& Salehi, H. (2016). Impact of WhatsApp on learning and retention of collocation knowledge among Iranian EFL learners. Advances in Language and Literary Studies, 7(5), 112-127.

[4] Basoglu, E., \& Akdemir, O. (2010). A comparison of undergraduate students' English vocabulary learning: Using cell phones and flash cards. The Turkish Online Journal of Educational Technology, 9(3), 1-14.

[5] Bere , A. (2013), Using WhatsApp mobile instant messaging to leverage learner participation and transform pedagogy at a South African University of Technology. British Journal of Educational Technology,44(4), 544-561. Retrieved on April 2020 from http://en.wikipedia.org /wiki/WhatsApp.

[6] Bouhnik, D., \& Deshen, M. (2014). WhatsApp goes to school: Mobile instant messaging between teachers and students. Retrieved on February 2020 from http://www.jite.org/documents/Vol13/ JITEv 13ResearchP217-231Bouhnik0601.pdf.

[7] Bryer, T., \& Zavattaro, S. (2011). Social media and public administration: Theoretical dimensions and introduction to symposium. Administrative theory \& praxis, 33(3), 325- 340.

[8] Chinnery, M. G. (2006). Going to the MALL: Mobile assisted language learning. Language learning and technology, 1(2), 916.

[9] Cohen, A. D., \& Weaver, S. J. (2005). Styles and strategies-based instruction: A teachers' guide. Minneapolis, MN: Center for Advanced Research on Language Acquisition, University of Minnesota.

[10] Collin, P., Richardson, I., \& Third, A. (2011). The benefits of social networking services. Cooperative research center for young people, Technology and wellbeing. Retrieved on April 2020 from http://www.fya.org.au/wpcontent/uploads/2010/07/The-Benefits-of-Social-NetworkingServices.pdf.

[11] Doughty, C., \& Williams, J. (1998). Pedagogical choices in focus on form. In C. Doughty \& J. Williams (Eds.), Focus on form in classroom second language acquisition (pp. 197-261). Cambridge: Cambridge University Press. 
[12] Ellis, R. (1995). Modified oral input and the acquisition of word meanings. Applied linguistics, 16(4), 409-441.

[13] Gascoigne, G. (2006). Toward an understanding of incidental input enhancement in computerized L2 environments. CALICO Journal, 24(2), 147-162.

[14] Graves, M. F. (2006). The vocabulary book: Learning and instruction. New York, NY: Teachers College Press.

[15] Homayounmehr, F., \& Pishdadi Motlagh, S. F. (2015). Investigating the effectiveness of input enhancement in relation to L2 vocabulary learning. International journal of language and linguistics, 4(2), 1-8. doi: 10.11648/j.ijll.s. 2016040201.11.

[16] Hornby, AS. (2004). Oxford advanced learner's dictionary. Oxford: Oxford University Press.

[17] Jadhav, D., Bhutkar, G., \& Mehta, V. (2013). Usability evaluation of messenger applications for Android phones using cognitive walkthrough. In Proceedings of the 11th Asia Pacific Conference on Computer Human Interaction (pp. 9-18). ACM.

[18] Jafari, S., \& Chalak, A. (2016). The role of WhatsApp in teaching vocabulary to Iranian EFL learners at junior high school. English Language Teaching, 9(8), 85-92.

[19] Jesa, M. (2008). Efficient English teaching. New Delhi: APH.

[20] Khabiri, M, \& Khatibi, M. B. (2013). Mobile-assisted language learning: Practices among Iranian EFL learners. European Online Journal of Natural and Social Sciences, 2(2), 176-190.

[21] Krashen, S. (1985). The input hypothesis: Issues and implications. Beverly Hills, CA: Laredo.

[22] Kukulska-Hulme, A., \& Shield, L. (2008). An Overview of Mobile Assisted Language Learning: from Content delivery to supported collaboration and interaction. ReCALL. 20 (3), 271 - 289.

[23] Lane, H.B., \& Allen, S.A. (2010). The vocabulary-rich classroom: Modeling sophisticated word use to promote word consciousness and vocabulary growth. The reading teacher, 63(5), 362-370.

[24] Lee, J., \& Benati, A. (2007). Delivering processing instruction in classrooms and virtual contexts: Research and practice. London: Equinox.

[25] Long, M. H., \& Robinson, P. (1998). Focus on form: Theory, research, and practice. In C. Doughty, \& J. Williams (Eds.). Focus on form in classroom second language acquisition (pp. 16-41). Cambridge: Cambridge University Press.

[26] Mckey, S. L. (2002). Teaching English as an international language: Rethinking goals and approaches. Oxford: Oxford University Press.

[27] Mohammed, E. F. (2009). The effectiveness of TPRS in vocabulary acquisition and retention of EFL prep stage students and their attitude towards English language (Unpublished master's thesis). Mansoura University, Egypt.

[28] Okar, N., \& Shahidy, S. H. (2018). Using Pictures of Movie Conversations with Input Enhancement in Subtitles for Developing Speaking of Iranian EFL Intermediate Learners. Journal of Applied Linguistics and TESOL (JALT), 2(2), 17-31.

[29] Olanof, D. (2012). WhatsApp hits new record with 10 billion total messages in one day. The Next Web.

[30] Oxenden, C., Latham-Koenig, C., \& Seligson, P. (2008). American English File. Oxford, UK: Oxford University Press

[31] Pempek, T. A., Yermolayeva, Y. A., \& Calvert, S. L. (2009). College students' social networking experiences on Facebook. Journal of applied developmental psychology, 30(3), 227-238. Retrieved from doi: 10.1016/j.appdev.2008.12.010.

[32] Pettit, J., \& Kukulska-Hulme, A. (2007). Going with the grain: Mobile devices in practice. Australasian journal of educational technology (AJET), 23(1), 17-33.

[33] Prensky, M. (2005). Listen to the natives. Educational leadership, 63(4), 8-13.

[34] Richards, J. C., \& Renandya, W. A. (2002). Methodology in language teaching: An anthology of current practice. Cambridge: Cambridge University Press.

[35] Sa'aleek, A. O. A. (2014). The Review of Emerging Technologies. Asian Journal of Education and e-Learning, 2 (6), 469 475.

[36] Sekiguchi, T. (2012). Neutrino facility and neutrino physics in J-PARC. Progress of theoretical and experimental physics, 20 (1), 2-5. Retrieved on May 2020 from http:// www ://doi.org/10.1093/ptep/pts020.

[37] Seyedtajaddini, K. (2014). The impact of audio input enhancement on EFL Learners' Grammar Learning from varying proficiency levels. Procedia - Social and Behavioral Sciences, 86 (2), 342-551.

[38] Sharwood Smith, M. (1993). Input enhancement in instructed SLA. Studies in second language acquisition, 15(2), $165-179$.

[39] Slaouti, D., Onat-Stelma, Z., \& Motteram, G. (2013). Technology and adult language teaching. Innovations in Learning Technologies for English Language Teaching. London: British Council.

[40] Souleyman, H. M. (2009). Implicit and Explicit Vocabulary Acquisition with a Computer-Assisted. Hypertext Reading Task: Comprehension and Retention (Unpublished Ph.D. Thesis). University of Arizona, USA.

[41] Sushma, P. (2012). Whats App founder to operators: We're no SMS killer, we get people hooked on data. The Next Web.

[42] Susilo, A. (2014). Exploring facebook and Whatsapp as supporting social network applications for English learning in higher education: Teaching and Learning in the 21st Century: Challenges for Lecturers and Teachers [special issue]. The Journal of Professional Development in Education. Retrieved on April 2020 from http://repository.widyatama. ac.id/xmlui/ bitstream/ handle/ 123456789/ 3317/002. \%20 Adhi\%20Susilo_Exploring \%20Facebook\%.

[43] Thornton, P., \& Houser, C. (2005). Using mobile phones in English education in Japan. Journal of computer assisted learning, $21(2), 217-228$.

[44] Traxler, J. (2005). Mobile learning: It's here, but what is it? Interactions, 9(1), 1-12.

[45] Trentin, G., \& Repetto, M. (2013). Using network and mobile technology to bridge formal and informal learning. Cambridge, UK: Woodhead/Chandos Publishing Limited.

[46] Trifanova, A., Knapp, J., Ronchetti, M., \& Gamper, J. (2004). Mobile ELDIT: challenges in the transitions from an e-learning to an m-learning system. Trento: University of Trento. Retrieved on May 2020 from http://eprint.Biblio. Unitn.it/archive/00000532/01/ paper 4911.pdf.

[47] Wei, M. (2007). An examination of vocabulary learning of college-level learners of English in China. Asian EFL Journal, 9 (2), $88-96$.

[48] Xodabande, I. (2017). The effectiveness of social media network telegram in teaching English language pronunciation to Iranian EFL learners. Retrieved on April 2020 from http:// www ://doi.org/10.1080/2331186X.2017.1347081. 
[49] Yousefzadeh, M. (2012). Mobile- based learning vs. paper-based learning and collocation words learning. Journal of Educational and Instructional Studies, 2(3), 216-220.

[50] Zhang, H., Song, W., \& Burston, J. (2011). Reexamining the effectiveness of vocabulary learning via mobile phones. The Turkish Online Journal of Educational Technology, 10(3), 203-214.

[51] Zoghi, M., \& Mirzaei, M. (2014). A comparative study of textual and visual contextualization on Iranian EFL learners' vocabulary learning. International Journal of Basic and Applied Science, 2(3), 31-40.

[52] Zulbeni, A. (2017). An analysis of grammatical errors in status and chatting among English teachers through whats app messenger. English Language Teaching and Research, 1(1), 47-64.

Yaghoob Javadi is an assistant professor of Applied Linguistics teaching postgraduate courses including Second Language Acquisition Studies, Curriculum Planning, Computer Enhanced Language Learning, and Language, Culture and Identity. His current research interests include cultural and cognitive aspects of second language acquisition, identity, CALL, curriculum planning and teacher education. ydjavadi@gmail.com

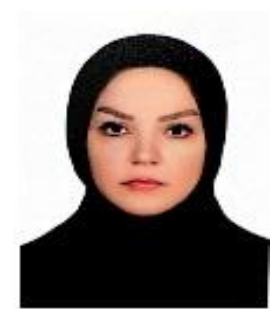

Maryam Cheraghi Shehni is a Ph.D candidate of Applied Linguistics at Department of Language Teaching and Translation Studies at Islamic Azad University. She is currently an English Language teacher. Her current research interests include Teacher education, Reading, CALL, ESP and Reflective teaching. shehni.mary@gmail.com 